\title{
THE EFFECT OF AN ARTERIOVENOUS FISTULA ON RENAL HEMODYNAMICS AND ELECTROLYTE EXCRETION ${ }^{1}$
}

\author{
By FRANKLIN H. EPSTEIN, ${ }^{2}$ ROBERT S. POST, AND MARION MCDOWELL ${ }^{3}$ \\ (From the Department of Cardiorespiratory Diseases, Army Medical Service Graduate School, \\ Washington, D. C.)
}

(Submitted for publication September 29, 1952; accepted November 26, 1952)

Patients with a compressible fistula between peripheral artery and vein provide a unique opportunity to study the reactions of the body to certain abrupt changes in the circulation. As has been said of the patient with congestive heart failure (1), the subject with an arteriovenous fistula is literally bleeding into his large veins. Opening or closing a fistula causes an immediate and marked change in peripheral resistance and a shift in the distribution of blood inside the vascular tree. This in turn elicits numerous compensatory adjustments (2-4).

It was of interest to examine the behavior of the kidneys in this situation for two reasons. First, the renal circulatory pattern in patients with arteriovenous fistulas has not been described. Secondly, it has been suggested that the kidneys retain or excrete sodium in response to alterations in the "effective" distribution of blood $(5,6)$. The present study permitted this hypothesis to be tested. The data presented show that glomerular filtration rate, renal blood flow and renal venous pressure do not change when a fistula is closed or opened, but demonstrate that the renal excretion of sodium is augmented when an arteriovenous shunt is compressed.

\section{METHODS}

Subjects were 17 young male casualties of the Korean war, treated on the Vascular Surgery Service of the Walter Reed Army Hospital. Each patient had a large arteriovenous fistula in the neck, shoulder, arm or leg, created by a penetrating wound received one and a half to five months previously. The diameters of the shunts as estimated at operation varied from 3 millimeters to 20

1 Presented in part before the American Physiological Society, Salt Lake City, Utah, September 6 to 8, 1951, and the American Federation for Clinical Research, Atlantic City, N. J., May 4, 1952.

2 Captain, M.C. Present address: 1st General Dispensary, Fort Richardson, Alaska.

Sajor, M.C. millimeters. No patient exhibited the signs or symptoms of congestive heart failure.

Patients were studied in the morning, in the postabsorptive state, while lying supine. After awaking, they were not permitted to get up and walk about before being wheeled in the supine position to the laboratory at $8 \mathrm{~A} . \mathrm{M}$. In all except four instances the subjects drank $240 \mathrm{cc}$. of water or hypotonic ( 0.14 per cent) saline every hour or half hour from 6:00 A.M. until the conclusion of the procedure, in order to insure a copious flow of urine. In seven experiments, including all those with initial urinary flows of less than $4.0 \mathrm{cc}$. per minute and collection periods of less than 20 minutes, urine was collected through an indwelling multi-eyed urethral catheter and the bladder was rinsed with distilled water and air. In the other studies, in which relatively high urinary flows and long collection periods minimized errors in the collection of urine, patients were permitted to stand briefly and void voluntarily. Clearances of inulin (7) and para-aminohippurate (8) were determined during constant infusion following a priming dose. Renal blood flow was calculated from the clearance of para-aminohippurate and venous hematocrit. In nine patients the clearance of endogenous creatinine was determined using a modification of the analytical technique of Bonsnes and Taussky (9). Concentrations of sodium and potassium in serum and urine were determined with a flame photometer. The method of Schales and Schales (10) was used to determine chloride in the urine of two patients. At intervals of two to five minutes throughout the procedure arterial pressure was measured with a sphygmomanometer and the pulse was counted for 30 seconds at the wrist. The mean blood pressure was arbitrarily taken to equal diastolic pressure plus $1 / 3$ of the pulse pressure (11). All data were analyzed for significance by the Fisher " $t$ " test.

Following a "CONTROL" period of at least 30 minutes, consisting of two or more clearance periods, the fistula was occluded by direct manual pressure over the fistula itself or the artery proximal to it, in such a fashion as to eliminate the characteristic bruit and to produce a definite elevation in diastolic blood pressure and slowing of the cardiac rate. "COMPRESSION" was maintained for 20 to 50 minutes while one to four collections of urine were made. After this the fistula was released and measurements were continued for another 20 to 50 minutes of "RECOVERY." After operative repair of the fistula, the same procedure was repeated in 12 patients, substituting pressure over the operative site or the opposite artery for compression of the previously existing fistula. 
RESULTS

\section{Blood pressure and pulse rate (Table I)}

Acute occlusion of an arteriovenous fistula in every instance caused an immediate and sustained increase in diastolic blood pressure, averaging 15 $\mathrm{mm}$. Hg. Systolic pressure rose less or not at all, and in four patients, actually fell slightly. During compression, therefore, the calculated mean arterial pressure increased, and the pulse pressure diminished in every case. The average rise in mean arterial pressure was $11 \mathrm{~mm}$. $\mathrm{Hg}$, with values ranging from 4 to $20 \mathrm{~mm}$. $\mathrm{Hg}$. In general, those patients with the largest arteriovenous communications, as estimated by the surgeon at the time of operation, demonstrated the most marked elevation of mean blood pressure when their fistulas were compressed. The cardiac rate of all patients slowed when the fistula was compressed and became more rapid when the shunt was released (Nicoladoni-Branham sign) $(12,13)$.

\section{Renal hemodynamics (Tables I and II, Figure 1)}

In all subjects except two (H. B. and F. R.) the clearance of inulin or endogenous creatinine was within normal limits. Renal blood flow was normal in all but one patient (R. J.), who had a bifid ureter demonstrated by intravenous pyelography, but no other evidence of renal disease. These values were not changed significantly by surgical repair of the fistula. Acute occlusion and release of an arteriovenous shunt produced no

TABLE I

Summary of data obtained in the seventeen patients studied pre-operatively

\begin{tabular}{|c|c|c|c|c|c|c|c|c|c|c|c|c|c|}
\hline Patient & $\begin{array}{l}\text { Location } \\
\text { of fistula }\end{array}$ & Procedure & $\begin{array}{l}\text { Dura- } \\
\text { tion } \\
\text { min- } \\
\text { utes }\end{array}$ & $\begin{array}{c}\text { Num- } \\
\text { ber } \\
\text { of } \\
\text { periods }\end{array}$ & $\underset{m m . \dot{H} g}{\text { B. }}$ & $\begin{array}{c}\text { Mean } \\
\text { press. } \\
\underset{H \boldsymbol{H}}{\boldsymbol{H}_{\boldsymbol{g}}}\end{array}$ & $\begin{array}{c}\text { Pulse } \\
\text { rate } \\
\text { beats/ } \\
\text { min. }\end{array}$ & $\begin{array}{l}\text { G.F.R.* } \\
\text { cc./min. } \\
\text { per } \\
1.73 \mathrm{m.}^{2}\end{array}$ & $\begin{array}{l}\text { R.B.F. } \\
\text { cc./min. } \\
\text { per } \\
1.73 \mathrm{m.}^{2}\end{array}$ & $\begin{array}{l}\text { Urine } \\
\text { flow } \\
c c . / m i n .\end{array}$ & 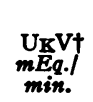 & 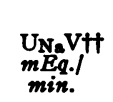 & $\mathrm{E} / \mathrm{F}_{\mathrm{Na}} \mathrm{S}$ \\
\hline 1. G. B. & Femoral & $\begin{array}{c}\text { Control } \\
\text { Compression } \\
\text { Recovery }\end{array}$ & $\begin{array}{l}44 \\
36 \\
48\end{array}$ & $\begin{array}{l}3 \\
3 \\
3\end{array}$ & $\begin{array}{l}91 / 53 \\
99 / 67 \\
97 / 57\end{array}$ & $\begin{array}{l}66 \\
78 \\
70\end{array}$ & $\begin{array}{l}88 \\
72 \\
85\end{array}$ & $\begin{array}{l}146 \\
142 \\
132\end{array}$ & $\begin{array}{l}1040 \\
1100 \\
1033\end{array}$ & $\begin{array}{l}1.5 \\
2.3 \\
1.6\end{array}$ & & $\begin{array}{l}0.151 \\
0.295 \\
0.171\end{array}$ & $\begin{array}{l}0.007 \\
0.014 \\
0.008\end{array}$ \\
\hline 2. G. M. & Femoral & $\begin{array}{l}\text { Contr. } \\
\text { Compr. } \\
\text { Recov. }\end{array}$ & $\begin{array}{l}40 \\
50 \\
26\end{array}$ & $\begin{array}{l}3 \\
5 \\
3\end{array}$ & $\begin{array}{l}94 / 62 \\
95 / 70 \\
97 / 69\end{array}$ & $\begin{array}{l}73 \\
78 \\
78\end{array}$ & $\begin{array}{l}77 \\
71 \\
78\end{array}$ & $\begin{array}{l}129 \\
127 \\
126\end{array}$ & $\begin{array}{l}1080 \\
1110 \\
1058\end{array}$ & $\begin{array}{l}5.2 \\
3.1 \\
3.3\end{array}$ & $\begin{array}{l}0.051 \\
0.045 \\
0.042\end{array}$ & $\begin{array}{l}0.231 \\
0.394 \\
0.310\end{array}$ & $\begin{array}{l}0.011 \\
0.020 \\
0.016\end{array}$ \\
\hline \multirow[t]{2}{*}{ 3. R. C. } & Femoral & $\begin{array}{l}\text { Contr. } \\
\text { Compr. } \\
\text { Recov. } \\
\text { Compr. }\end{array}$ & $\begin{array}{l}59 \\
31 \\
31 \\
30\end{array}$ & $\begin{array}{l}2 \\
1 \\
1 \\
1\end{array}$ & $\begin{array}{l}120 / 69 \\
121 / 82 \\
121 / 64 \\
121 / 84\end{array}$ & $\begin{array}{l}86 \\
95 \\
83 \\
96\end{array}$ & $\begin{array}{l}73 \\
58 \\
76 \\
54\end{array}$ & $\begin{array}{l}126 \\
132 \\
148 \\
138\end{array}$ & $\begin{array}{l}1098 \\
1065 \\
1185 \\
1082\end{array}$ & $\begin{array}{l}5.0 \\
4.4 \\
2.4 \\
3.7\end{array}$ & & $\begin{array}{l}0.320 \\
0.512 \\
0.331 \\
0.392\end{array}$ & $\begin{array}{l}0.015 \\
0.022 \\
0.013 \\
0.016\end{array}$ \\
\hline & & $\begin{array}{l}\text { Contr. } \\
\text { Compr. } \\
\text { Recov. }\end{array}$ & $\begin{array}{r}113 \\
32 \\
60\end{array}$ & $\begin{array}{l}2 \\
1 \\
2\end{array}$ & $\begin{array}{l}119 / 73 \\
117 / 80 \\
117 / 69\end{array}$ & $\begin{array}{l}88 \\
92 \\
85\end{array}$ & $\begin{array}{l}77 \\
59 \\
77\end{array}$ & $\begin{array}{l}117 \\
111 \\
100\end{array}$ & & $\begin{array}{l}17.9 \\
19.5 \\
11.6\end{array}$ & $\begin{array}{l}0.035 \\
0.021 \\
0.022\end{array}$ & $\begin{array}{l}0.199 \\
0.318 \\
0.209\end{array}$ & $\begin{array}{l}0.012 \\
0.021 \\
0.021\end{array}$ \\
\hline 4. W. G. & Femoral & $\begin{array}{l}\text { Contr. } \\
\text { Compr. } \\
\text { Recov. }\end{array}$ & $\begin{array}{l}31 \\
21 \\
33\end{array}$ & $\begin{array}{l}2 \\
2 \\
3\end{array}$ & $\begin{array}{l}112 / 41 \\
105 / 65 \\
115 / 45\end{array}$ & $\begin{array}{l}65 \\
78 \\
68\end{array}$ & $\begin{array}{r}109 \\
94 \\
109\end{array}$ & $\begin{array}{l}112 \\
117 \\
109\end{array}$ & $\begin{array}{l}1023 \\
1082 \\
1098\end{array}$ & $\begin{array}{l}3.0 \\
4.6 \\
3.3\end{array}$ & & $\begin{array}{l}0.218 \\
0.287 \\
0.180\end{array}$ & $\begin{array}{l}0.014 \\
0.018 \\
0.012\end{array}$ \\
\hline 5. R. J. & $\begin{array}{l}\text { Sub- } \\
\text { clavian }\end{array}$ & $\begin{array}{l}\text { Contr. } \\
\text { Compr. } \\
\text { Recov. }\end{array}$ & $\begin{array}{l}41 \\
33 \\
44\end{array}$ & $\begin{array}{l}3 \\
2 \\
4\end{array}$ & $\begin{array}{l}104 / 41 \\
108 / 76 \\
111 / 48\end{array}$ & $\begin{array}{l}62 \\
87 \\
69\end{array}$ & $\begin{array}{l}75 \\
52 \\
76\end{array}$ & $\begin{array}{l}117 \\
104 \\
113\end{array}$ & $\begin{array}{l}648 \\
554 \\
660\end{array}$ & $\begin{array}{l}6.7 \\
5.2 \\
5.2\end{array}$ & & $\begin{array}{l}0.160 \\
0.200 \\
0.158\end{array}$ & $\begin{array}{l}0.009 \\
0.013 \\
0.009\end{array}$ \\
\hline 6. J. C. & Femoral & $\begin{array}{l}\text { Contr. } \\
\text { Compr. } \\
\text { Recov. } \\
\text { Compr. }\end{array}$ & $\begin{array}{l}38 \\
44 \\
35 \\
10\end{array}$ & $\begin{array}{l}3 \\
3 \\
3 \\
1\end{array}$ & $\begin{array}{l}134 / 53 \\
130 / 80 \\
136 / 51 \\
143 / 88\end{array}$ & $\begin{array}{r}80 \\
97 \\
79 \\
106\end{array}$ & $\begin{array}{l}69 \\
56 \\
70 \\
58\end{array}$ & $\begin{array}{l}143 \\
129 \\
134 \\
125\end{array}$ & $\begin{array}{l}830 \\
831 \\
755 \\
816\end{array}$ & $\begin{array}{l}2.1 \\
2.6 \\
2.0 \\
3.5\end{array}$ & $\begin{array}{l}0.029 \\
0.024 \\
0.022\end{array}$ & $\begin{array}{l}0.298 \\
0.321 \\
0.260 \\
0.343\end{array}$ & $\begin{array}{l}0.012 \\
0.014 \\
0.011 \\
0.016\end{array}$ \\
\hline 7. G.S. & Carotid & $\begin{array}{l}\text { Contr. } \\
\text { Compr. } \\
\text { Recov. }\end{array}$ & $\begin{array}{l}51 \\
39 \\
41\end{array}$ & $\begin{array}{l}2 \\
1 \\
1\end{array}$ & $\begin{array}{l}102 / 61 \\
108 / 78 \\
105 / 59\end{array}$ & $\begin{array}{l}75 \\
88 \\
74\end{array}$ & $\begin{array}{l}69 \\
49 \\
71\end{array}$ & $\begin{array}{r}103 \\
110 \\
97\end{array}$ & $\begin{array}{l}742 \\
875 \\
723\end{array}$ & $\begin{array}{l}3.9 \\
6.8 \\
3.4\end{array}$ & & $\begin{array}{l}0.115 \\
0.202 \\
0.091\end{array}$ & $\begin{array}{l}0.007 \\
0.011 \\
0.008\end{array}$ \\
\hline \multirow[t]{2}{*}{ 8. J. F. } & Brachial. & $\begin{array}{l}\text { Contr. } \\
\text { Compr. } \\
\text { Recov. }\end{array}$ & $\begin{array}{l}72 \\
31 \\
51\end{array}$ & $\begin{array}{l}3 \\
1 \\
2\end{array}$ & $\begin{array}{l}131 / 80 \\
127 / 88 \\
123 / 78\end{array}$ & $\begin{array}{r}97 \\
101 \\
93\end{array}$ & $\begin{array}{l}76 \\
64 \\
77\end{array}$ & $\begin{array}{r}111 \\
97 \\
121\end{array}$ & $\begin{array}{l}785 \\
653 \\
760\end{array}$ & $\begin{array}{l}13.0 \\
13.6 \\
14.9\end{array}$ & & $\begin{array}{l}0.370 \\
0.313 \\
0.324\end{array}$ & $\begin{array}{l}0.023 \\
0.023 \\
0.019\end{array}$ \\
\hline & & $\begin{array}{l}\text { Compr. } \\
\text { Recov. } \\
\text { Compr. }\end{array}$ & $\begin{array}{l}36 \\
33 \\
36\end{array}$ & $\begin{array}{l}3 \\
3 \\
3\end{array}$ & $\begin{array}{l}118 / 84 \\
117 / 78 \\
125 / 92\end{array}$ & $\begin{array}{r}95 \\
91 \\
103\end{array}$ & $\begin{array}{l}77 \\
85 \\
74\end{array}$ & $\begin{array}{l}108 \\
111 \\
102\end{array}$ & $\begin{array}{l}704 \\
686 \\
655\end{array}$ & $\begin{array}{l}1.2 \\
1.1 \\
1.1\end{array}$ & & $\begin{array}{l}0.196 \\
0.180 \\
0.223\end{array}$ & $\begin{array}{l}0.012 \\
0.011 \\
0.014\end{array}$ \\
\hline
\end{tabular}


TABLE I-Continued

\begin{tabular}{|c|c|c|c|c|c|c|c|c|c|c|c|c|c|}
\hline Patient & $\begin{array}{l}\text { Location } \\
\text { of fistula }\end{array}$ & Procedure & $\begin{array}{c}\text { Dura- } \\
\text { tion } \\
\text { min. } \\
\text { ules }\end{array}$ & $\begin{array}{c}\text { Num- } \\
\text { ber } \\
\text { of } \\
\text { periods }\end{array}$ & B.P. & $\begin{array}{c}\text { Mean } \\
\text { press. } \\
m_{\boldsymbol{B}} \\
\end{array}$ & $\begin{array}{l}\text { Pulse } \\
\text { rate } \\
\text { beatsls } \\
\text { min. }\end{array}$ & $\begin{array}{l}\text { G.F.R.* } \\
\text { cc./min. } \\
1.73 \text { per }^{2}\end{array}$ & $\begin{array}{l}\text { R.B.F. } \\
\text { cc./min. } \\
\text { per } \\
1.73 \mathrm{m.2}\end{array}$ & $\begin{array}{c}\text { Urine } \\
\text { flow } \\
\text { cc.omin. }\end{array}$ & $\begin{array}{c}U_{\mathrm{KVH}} \\
\boldsymbol{m E q .} \\
\boldsymbol{m i n .} \\
\end{array}$ & 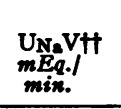 & $\mathrm{E} / \mathrm{F}_{\mathrm{Na}} \mathrm{S}$ \\
\hline 9. W. T. & Carotid & $\begin{array}{l}\text { Contr. } \\
\text { Compr. } \\
\text { Recov. }\end{array}$ & $\begin{array}{l}32 \\
46 \\
31\end{array}$ & $\begin{array}{l}3 \\
4 \\
3\end{array}$ & $\begin{array}{l}104 / 64 \\
108 / 73 \\
103 / 67\end{array}$ & $\begin{array}{l}77 \\
85 \\
79\end{array}$ & $\begin{array}{l}71 \\
66 \\
99\end{array}$ & $\begin{array}{l}137 \\
131 \\
116\end{array}$ & $\begin{array}{l}1327 \\
1158 \\
1245\end{array}$ & $\begin{array}{l}3.2 \\
4.2 \\
1.3\end{array}$ & & $\begin{array}{l}0.071 \\
0.114 \\
0.122\end{array}$ & $\begin{array}{l}0.003 \\
0.006 \\
0.007\end{array}$ \\
\hline 10. D. B. & Popliteal & $\begin{array}{l}\text { Contr. } \\
\text { Compr. } \\
\text { Recov. }\end{array}$ & $\begin{array}{l}87 \\
45 \\
45\end{array}$ & $\begin{array}{l}2 \\
1 \\
1\end{array}$ & $\begin{array}{l}105 / 60 \\
111 / 68 \\
115 / 63\end{array}$ & $\begin{array}{l}75 \\
82 \\
80\end{array}$ & $\begin{array}{l}70 \\
62 \\
72\end{array}$ & $\begin{array}{l}118 \\
128 \\
116\end{array}$ & & $\begin{array}{l}5.6 \\
2.6 \\
5.2\end{array}$ & $\begin{array}{l}0.144 \\
0.190 \\
0.178\end{array}$ & $\begin{array}{l}0.280 \\
0.514 \\
0.368\end{array}$ & $\begin{array}{l}0.015 \\
0.026 \\
0.020\end{array}$ \\
\hline 11. J. T. & $\begin{array}{l}\text { Thoraco- } \\
\text { acromial }\end{array}$ & $\begin{array}{l}\text { Contr. } \\
\text { Compr. } \\
\text { Recov. }\end{array}$ & $\begin{array}{l}29 \\
30 \\
60\end{array}$ & $\begin{array}{l}1 \\
1 \\
2\end{array}$ & $\begin{array}{l}98 / 52 \\
99 / 66 \\
97 / 59\end{array}$ & $\begin{array}{l}67 \\
77 \\
72\end{array}$ & $\begin{array}{l}62 \\
56 \\
61\end{array}$ & $\begin{array}{l}120 \\
116 \\
117\end{array}$ & & $\begin{array}{l}8.5 \\
5.3 \\
4.1\end{array}$ & $\begin{array}{l}0.135 \\
0.113 \\
0.108\end{array}$ & $\begin{array}{l}0.132 \\
0.184 \\
0.152\end{array}$ & $\begin{array}{l}0.006 \\
0.009 \\
0.007\end{array}$ \\
\hline 12. E. B. & Femoral & $\begin{array}{l}\text { Contr. } \\
\text { Compr. } \\
\text { Recov. }\end{array}$ & $\begin{array}{r}135 \\
28 \\
58\end{array}$ & $\begin{array}{l}4 \\
1 \\
2\end{array}$ & $\begin{array}{l}116 / 45 \\
121 / 73 \\
124 / 52\end{array}$ & $\begin{array}{l}69 \\
89 \\
76\end{array}$ & $\begin{array}{l}78 \\
65 \\
79\end{array}$ & $\begin{array}{r}105 \\
94 \\
111\end{array}$ & & $\begin{array}{l}7.8 \\
8.5 \\
4.8\end{array}$ & $\begin{array}{l}0.075 \\
0.088 \\
0.078\end{array}$ & $\begin{array}{l}0.127 \\
0.273 \\
0.235\end{array}$ & \\
\hline 13. A. D. & Femoral & $\begin{array}{l}\text { Contr. } \\
\text { Compr. } \\
\text { Recov. }\end{array}$ & $\begin{array}{l}69 \\
20 \\
30\end{array}$ & $\begin{array}{l}3 \\
1 \\
1\end{array}$ & $\begin{array}{l}111 / 56 \\
114 / 73 \\
114 / 58\end{array}$ & $\begin{array}{l}72 \\
87 \\
73\end{array}$ & $\begin{array}{l}66 \\
50 \\
68\end{array}$ & $\begin{array}{r}100 \\
100 \\
91\end{array}$ & & $\begin{array}{l}8.7 \\
9.6 \\
6.1\end{array}$ & $\begin{array}{l}0.095 \\
0.103 \\
0.087\end{array}$ & $\begin{array}{l}0.110 \\
0.147 \\
0.123\end{array}$ & $\begin{array}{l}0.008 \\
0.011 \\
0.010\end{array}$ \\
\hline 14. H. B. & Popliteal & $\begin{array}{l}\text { Contr. } \\
\text { Compr. } \\
\text { Recov. }\end{array}$ & $\begin{array}{l}57 \\
29 \\
20\end{array}$ & $\begin{array}{l}2 \\
1 \\
1\end{array}$ & $\begin{array}{l}116 / 45 \\
113 / 62 \\
118 / 48\end{array}$ & $\begin{array}{l}69 \\
79 \\
71\end{array}$ & $\begin{array}{l}76 \\
56 \\
78\end{array}$ & $\begin{array}{l}78 \\
72 \\
77\end{array}$ & & $\begin{array}{r}9.8 \\
13.5 \\
8.4\end{array}$ & & $\begin{array}{l}0.252 \\
0.345 \\
0.250\end{array}$ & $\begin{array}{l}0.023 \\
0.034 \\
0.023\end{array}$ \\
\hline 15. H.F. & Popliteal & $\begin{array}{l}\text { Contr. } \\
\text { Compr. } \\
\text { Recov. }\end{array}$ & $\begin{array}{l}50 \\
20 \\
28\end{array}$ & $\begin{array}{l}2 \\
1 \\
1\end{array}$ & $\begin{array}{l}126 / 76 \\
132 / 82 \\
125 / 75\end{array}$ & $\begin{array}{l}93 \\
99 \\
92\end{array}$ & $\begin{array}{l}63 \\
54 \\
65\end{array}$ & $\begin{array}{l}140 \\
137 \\
143\end{array}$ & & $\begin{array}{r}12.6 \\
11.1 \\
6.0\end{array}$ & & $\begin{array}{l}0.182 \\
0.228 \\
0.228\end{array}$ & $\begin{array}{l}0.009 \\
0.012 \\
0.011\end{array}$ \\
\hline 16. W. R. & Femoral & $\begin{array}{l}\text { Contr. } \\
\text { Compr. } \\
\text { Recov. }\end{array}$ & $\begin{array}{l}65 \\
31 \\
32\end{array}$ & $\begin{array}{l}2 \\
1 \\
1\end{array}$ & $\begin{array}{r}100 / 52 \\
100 / 58 \\
98 / 52\end{array}$ & $\begin{array}{l}68 \\
72 \\
67\end{array}$ & $\begin{array}{l}85 \\
68 \\
80\end{array}$ & $\begin{array}{l}146 \\
144 \\
151\end{array}$ & & $\begin{array}{l}7.9 \\
7.0 \\
6.7\end{array}$ & & $\begin{array}{l}0.079 \\
0.099 \\
0.079\end{array}$ & $\begin{array}{l}0.004 \\
0.005 \\
0.004\end{array}$ \\
\hline 17. F. R. & Femoral & $\begin{array}{l}\text { Contr. } \\
\text { Compr. } \\
\text { Recov. }\end{array}$ & $\begin{array}{r}120 \\
26 \\
26\end{array}$ & $\begin{array}{l}4 \\
1 \\
1\end{array}$ & $\begin{array}{l}112 / 57 \\
111 / 78 \\
116 / 61\end{array}$ & $\begin{array}{l}75 \\
89 \\
79\end{array}$ & $\begin{array}{l}66 \\
58 \\
71\end{array}$ & $\begin{array}{l}82 \\
89 \\
83\end{array}$ & & $\begin{array}{l}5.4 \\
7.1 \\
5.6\end{array}$ & $\begin{array}{l}0.038 \\
0.036 \\
0.029\end{array}$ & $\begin{array}{l}0.046 \\
0.085 \\
0.042\end{array}$ & $\begin{array}{l}0.004 \\
0.007 \\
0.004\end{array}$ \\
\hline \multicolumn{2}{|c|}{ Mean } & $\begin{array}{l}\text { Contr. } \\
\text { Compr. } \\
\text { Recov. }\end{array}$ & & & $\begin{array}{l}111 / 59 \\
112 / 74^{* *} \\
113 / 61^{* *}\end{array}$ & $\begin{array}{l}76 \\
87^{* *} \\
78^{* *}\end{array}$ & $\begin{array}{l}76 \\
62^{* *} \\
78^{* *}\end{array}$ & $\begin{array}{l}118 \\
115 \\
115\end{array}$ & $\begin{array}{l}926 \\
913 \\
920\end{array}$ & $\begin{array}{l}6.8 \\
7.0 \\
5.1\end{array}$ & $\begin{array}{l}0.075 \\
0.077 \\
0.071\end{array}$ & $\begin{array}{l}0.185 \\
0.267^{* *} \\
0.200^{* *}\end{array}$ & $\begin{array}{l}0.011 \\
0.016^{* *} \\
0.012^{* *}\end{array}$ \\
\hline
\end{tabular}

inulin. Indicates "highly significant" change from the preceding value $(P<0.01)$.

$\dagger U_{K} V=$ Urine concentration of potassium in $\mathrm{mEq} . / \mathrm{cc}$. $\times$ Urine volume flow in $\mathrm{cc} . / \mathrm{min}$. = milliequivalents of potassium excreted in the urine per minute time.

t† $\mathrm{U}_{\mathrm{Na}} \mathrm{V}=$ Urine concentration of sodium in $\mathrm{mEq} . / \mathrm{cc}$. $\times$ Urine volume flow in cc./min. = milliequivalents of sodium excreted in the urine per minute time.

$\S \mathrm{E}=\mathrm{U}_{\mathrm{Na}} \mathrm{V}$. $\mathrm{F}_{\mathrm{Na}}=$ Plasma concentration of sodium in $\mathrm{mEq} . / \mathrm{cc} . \times$ Glomerular filtration rate in cc. $/ \mathrm{min} .=$ $\mathrm{mEq}$./min. of sodium filtered by the glomeruli. Hence $\mathrm{E} / \mathrm{F}_{\mathrm{N}_{\mathrm{a}}}$ represents the ratio of excreted to filtered sodium.

consistent or significant change in the clearances of inulin, endogenous creatinine chromogen, or PAH; the filtration fraction, therefore, was also unaffected. The venous hematocrit was similarly unaltered. The left renal vein was catheterized in six patients (patients 12 to 17 , Table I), in order to measure its pressure directly. Renal venous pressure was within normal limits $(6$ to $10 \mathrm{~mm}$. $\mathrm{Hg}$ ) (14) and was unaltered by temporary closure or opening of the arteriovenous fistula.

Since renal blood flow remained essentially unchanged when a fistula was occluded, despite a rise in the mean arterial pressure perfusing the kidneys, the total renal vascular resistance must have increased. If the data of Table I are analyzed according to the concepts of Gomez (15) it is apparent that this was accomplished largely by an increase in renal "afferent" arteriolar resistance.

\section{Excretion of electrolytes and water}

In contrast to the relative constancy of renal blood flow and glomerular filtration rate, the excretion of sodium increased significantly $(P<$ 0.01 ) when the fistula was compressed in every 

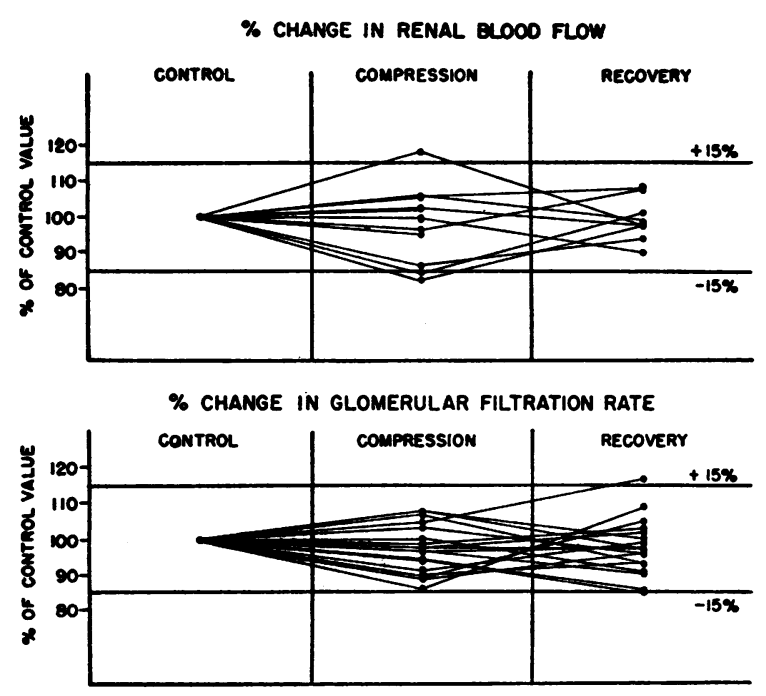

FIG. 1

experiment except one (Table I, Figure 2). The increase ranged from 0.020 milliequivalents per minute to 0.234 milliequivalents per minute and the average rate of sodium excretion during the period of compression was 144 per cent of control. The effect could not be quantitatively correlated with the size of the shunt as estimated at operation or with the magnitude of the response
TABLE II

Comparison of pre- and post-operative glomerular filtration rate and renal blood flow

\begin{tabular}{lccccr}
\hline \hline & \multicolumn{2}{c}{ GFR* } & & \multicolumn{2}{c}{ RBF } \\
\cline { 5 - 6 } Pt. & cc./min./1.73 m.2 & & \multicolumn{2}{c}{ cc/min./1.73 m.2 } \\
\cline { 2 - 3 } \cline { 5 - 6 } & pre & post & & pre & post \\
\hline G. B. & 146 & 137 & & 1,040 & 1,194 \\
P. M. & 129 & 113 & & 1,080 & 1,008 \\
R. C. & 126 & 133 & & 1,098 & 1,455 \\
W. G. & 112 & 102 & & 1,023 & 874 \\
R. J. & 117 & 112 & & 648 & 635 \\
J. C. & 143 & 129 & & 830 & 914 \\
G. S. & 139 & 112 & & 923 & 1,030 \\
J.F. & 111 & 126 & & 785 & 810 \\
Mean & 128 & 120 & & 928 & 990
\end{tabular}

* Clearances of inulin. Each value represents the average of three collection periods.

There is no consistent or significant difference between the values before and after repair of an $A-V$ fistula.

of the blood pressure to occlusion. An augmented excretion of sodium was apparent in urine collected 10 to 15 minutes after occlusion of the fistula and continued throughout the compression period. After the fistula was released, sodium excretion fell toward control values in all but two instances. In two patients the urinary excretion of chloride was measured and found to parallel that of sodium. Following surgical repair of the

\section{\% CHANGE IN No EXCRETION}

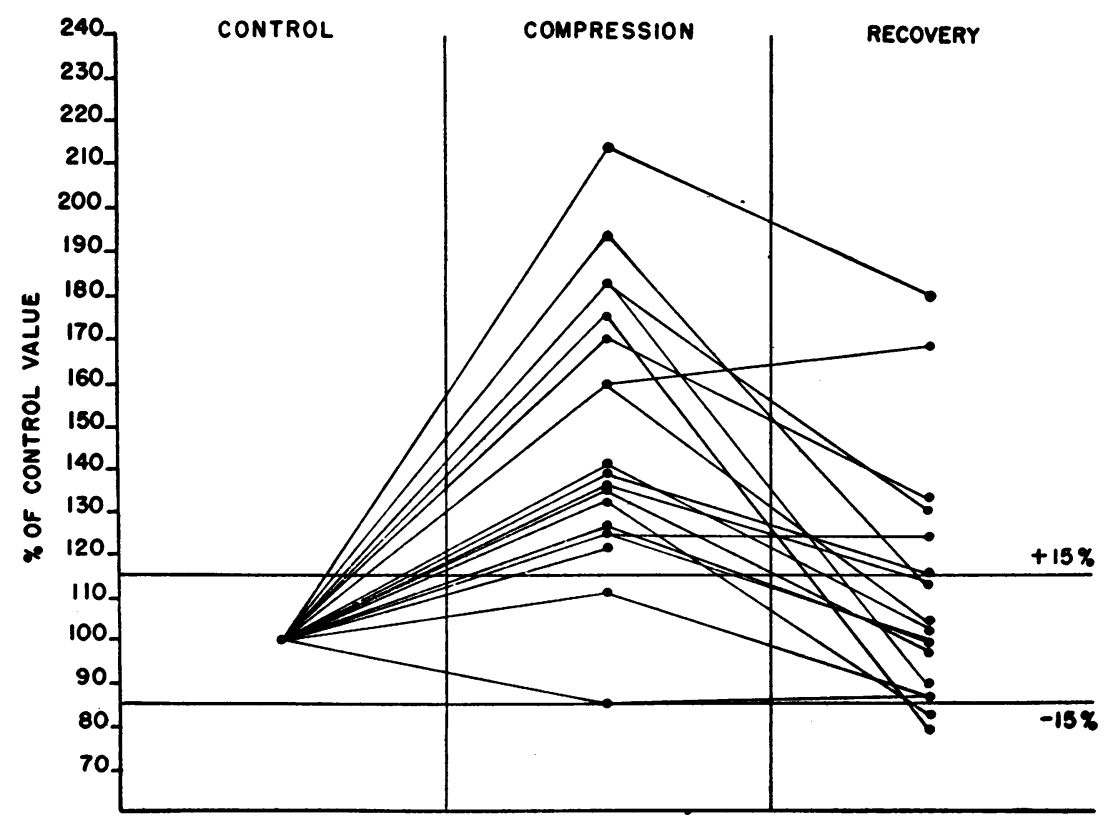

FIG. 2 


\section{POSTOPERATIVE CHANGES IN NO EXCRETION} WITH ARTERIAL COMPRESSION

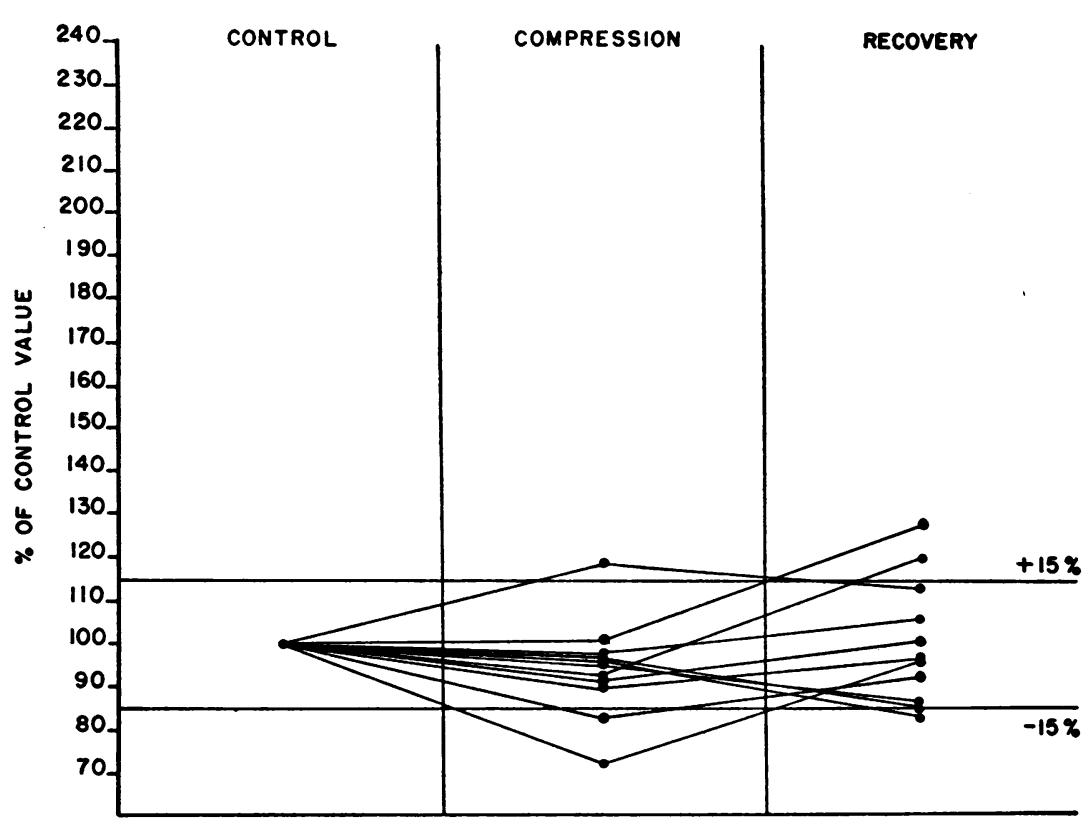

FIG. 3

fistula (Figure 3), renal excretion of sodium was unchanged by manual occlusion of an artery at the operative site or in the opposite limb, a procedure which did not produce significant changes in cardiac output or arterial pressure (16).

The renal excretion of potassium, studied in six patients, was not consistently altered by temporary closure or release of an arteriovenous shunt.

The flow of urine increased in 12 of 19 experiments when the fistula was closed, and diminished during the recovery period in 16 . Interpretation of these findings is complicated by the fact that most of the patients had been drinking and were in positive water balance, and by the well-known tendency for urinary flow to fall off toward the end of a long and sometimes tiring procedure (17).

\section{DISCUSSION}

It is pertinent to review briefly the effects upon the general circulation of closing and opening an arteriovenous fistula and to consider how they might influence the kidneys. When an arteriovenous shunt is occluded, the arterial tree is emptied more slowly and less completely, and mean arterial pressure rises. Pressures in the great veins, the right atrium, and the pulmonary vessels tend to fall as these regions become less distended with blood $(3,18-21)$. Cardiac output is decreased as the heart rate slows and stroke volume diminishes. When the fistula is opened, blood pours from arteries into veins. Despite an increase in cardiac output $(3,4,19,22-24)$, the arteries become less distended, and mean systemic arterial pressure falls, while the great veins become more swollen and pressures in the right atrium and pulmonary artery may increase (3, 18-20).

The effects of sudden changes in renal vascular pressures, similar to those occurring in the present experiments, on renal hemodynamics, urinary flow and electrolyte excretion have been extensively studied in isolated kidneys and anesthetized animals, and have recently been discussed in detail (25-27). The kidneys of such preparations, whether or not the renal nerves are intact, exhibit a remarkable ability to maintain a constant rate of blood flow and glomerular filtration, in the face of wide variations in mean arterial perfusing pressure. Renal blood flow and filtration rate were similarly unaffected in the present study by the changes in mean arterial pressure accompanying closure and release of an arteriovenous 
fistula, so that in contrast to the reported response of other vascular beds $(3,28,29)$, the renal vascular resistance regularly increased when a peripheral fistula was occluded and decreased when it was opened. Presumably this is a manifestation of the "autonomy" of the renal vasculature expressed, in intact subjects (30-32) as in the isolated kidney, primarily through changes in afferent renal arteriolar resistance.

When an arteriovenous fistula is occluded, arterial pulse pressure is diminished at the same time that the excretion of sodium is augmented. A narrowed pulse pressure was thought by Hooker (33) and Gesell (34) to result in antidiuresis and retention of chloride. More recently it has been shown by Selkurt (35) and by Goodyer and Glenn (36) that alterations in renal arterial pulse pressure per se are not necessarily followed by changes in the excretion of sodium. On the other hand, an increase in the mean arterial pressure perfusing one kidney has been reported by Selkurt to induce a unilateral diuresis of salt and water without greatly changing the glomerular filtration rate (35). In all subjects of the present study, the increase in sodium excretion produced by closing a fistula was accompanied by an elevation of the calculated mean arterial pressure. However, the increase in pressure was always much smaller than that required in Selkurt's experiments to bring about the change in sodium excretion. Furthermore, the changes in sodium excretion from patient to patient could not be correlated with the magnitude of the response of the blood pressure.

The fraction of filtered sodium rejected by the tubules and appearing in the urine $\left(E / F_{N a}\right)$ increased in all patients except one when flow through the fistula was shut off. In the absence of a consistent increase in the clearance of inulin or endogenous creatinine, the increase in renal excretion of sodium might be construed to be the result of altered tubular behavior toward this ion, presumably because of changes in nervous, hormonal or intrinsic renal influences. Unfortunately present techniques for the measurement of glomerular filtration are not accurate enough to rule out completely the possibility that an undetected increase in the filtration of sodium might have occurred to account for the observed increment in sodium excretion.

The present findings might be considered an example of the regulatory role of the kidneys in opposing distortions in the volume and distribution of the fluids of the body. It has long been realized that renal excretion of salt and water must be conditioned by the volume of body fluids, as well as by their tonicity (37), and it has been reasoned that renal excretion or retention of sodium may be related to some function of the volume of the circulating blood (38). Others have suggested that diuresis may be stimulated by an increase, and depressed by a reduction, in the cardiac output (39). Studies of the effects of posture on diuresis support the view that the effective distribution of blood rather than its total volume is important in influencing renal behavior $(6,40,41)$. The great veins (42), the right heart and pulmonary artery (43), the cranial cavity (44), the "cephalad portion of the body" (45), and the arterial pressoreceptors (46) have all been proposed as possible sites for the initiation of afferent impulses designed to modify renal excretion of salt or water. Since the distribution of blood in the vascular tree of a patient with an arteriovenous communication is altered acutely when the shunt is occluded or released, the present study provides additional information by which to evaluate these hypotheses. The data suggest that an increase in arterial pressure or arterial filling may initiate a chain of events culminating in an increased renal excretion of sodium. If this were true, the experimental creation of a large arteriovenous fistula might be expected to promote the renal retention of salt, at least until a new equilibrium is established. This sequence of events has in fact been observed (47, 48).

It is interesting to list the circulatory states, chronic as well as acute, in which the kidneys tend to retain sodium. Dehydration (49), hypoproteinemia $(50,51)$, and hemorrhage $(52,53)$ are associated with a diminution in total blood volume. In quiet standing (6), venous congestion of the limbs $(54,55)$, partial occlusion of the superior or inferior vena cava (56), and portal hypertension (57), filtration from the capillaries is increased and in addition blood is pooled in the peripheral veins, away from the general circulation. Acute (58) and chronic $(59,60)$ constrictive pericarditis, constriction of the pulmonary artery $(61,62)$ and congestive heart failure are characterized by distention of the central veins with blood which 
the heart is unable to pump efficiently into the aorta. In some of the above conditions the volume of blood in the central veins is reduced; in others these vessels are engorged. In all, however, there exists a tendency toward inadequate filling of the systemic arterial tree, either because of a diminished total blood volume or an altered distribution of blood within the vascular system. The latter may have its origin either in pooling or shunting of blood in the periphery or in failure of the heart as a pump. The changes in sodium excretion, described in the present communication, which accompany occlusion or release of an arteriovenous fistula, are consistent with the hypothesis that renal excretion or retention of sodium is conditioned by the degree of filling of some portion of the arterial tree.

\section{SUMMARY}

Occlusion of an established arteriovenous fistula results in an increased renal excretion of sodium. This accompanies the well-known rise in diastolic arterial pressure and slowing of the cardiac rate, despite no change in glomerular filtration rate, renal blood flow or renal venous pressure. The latter values are usually normal and are not altered significantly by surgical repair of the fistula. The data suggest that renal excretion of sodium may be conditioned by the degree of filling of some portion of the arterial tree.

\section{ACKNOWLEDGMENTS}

The authors gratefully acknowledge the cooperation and help of Brig. Gen. Sam Seeley, Lt. Col. Carl Hughes, and Maj. Edward Jahnke, of the Surgical Service of the Walter Reed Army Hospital.

\section{REFERENCES}

1. Bazett, H. C., Blood volume and cardiovascular adjustments. Am. Heart J., 1941, 21, 423.

2. Lewis, T., and Drury, A. N., Observations relating to arteriovenous aneurism. I. Circulatory manifestations in clinical cases with particular references to the arterial phenomena of aortic regurgitation. II. The immediate effects of an arteriovenous anastomosis on the dog's circulation. Heart, 1923, 10, 301.

3. Cohen, S. M., Edholm, O. G., Howarth, S., McMichael, J., and Sharpey-Schafer, E. P., Cardiac output and peripheral bloodflow in arteriovenous aneurysm. Clin. Science, 1948, 7, 35.

4. Van Loo, A., and Heringman, E. C., Circulatory changes in the dog produced by acute arteriovenous fistula. Am. J. Physiol., 1949, 158, 103.

5. Peters, J. P., The problem of cardiac edema. Am. J. Med., 1952, 12, 66.

6. Epstein, F. H., Goodyer, A. V. N., Lawrason, F. D., and Relman, A. S., Studies of the antidiuresis of quiet standing : the importance of changes in plasma volume and glomerular filtration rate. J. Clin. Invest., 1951, 30, 63.

7. Schreiner, G. E., Determination of inulin by means of resorcinol. Proc. Soc. Exper. Biol. \& Med. 1950, 74, 117.

8. Smith, H. W., Finkelstein, N., Aliminosa, L., Crawford, B., and Graber, M., The renal clearances of substituted hippuric acid derivatives and other aromatic acids in dog and man. J. Clin. Invest., 1945, 24, 388.

9. Bonsnes, R. W., and Taussky, H. H., On the colorimetric determination of creatinine by the Jaffe reaction. J. Biol. Chem., 1945, 158, 581.

10. Schales, O., and Schales, S. S., A simple and accurate method for the determination of chloride in biological fluids. J. Biol. Chem., 1941, 140, 879.

11. Bazett, H. C., The circulation. Part III, in MacLeod's Physiology in Modern Medicine, 9th Edition, Ed. by Philip Bard. St. Louis, 1941, C. V. Mosby, pp. 295-533.

12. Nicalodoni, C., Phlebarteriectasie der rechten oberen extremität. Arch. f. Klin. Chir., 1875, 18, 252.

13. Branham, H. H., Aneurismal varix of the femoral artery and vein following a gunshot wound. Internat. J. Surg., 1890, 3, 250.

14. Maxwell, M. H., Breed, E. S., and Schwartz, I. L., Renal venous pressure in chronic congestive heart failure. J. Clin. Invest., 1950, 29, 342.

15. Gomez, D. M., Evaluation of renal resistances, with special reference to changes in essential hypertension. J. Clin. Invest., 1951, 30, 1143.

16. Epstein, F. H., McDowell, M., Shadle, O., and Ferguson, T. B., Unpublished observations.

17. Smith, H. W., The Kidney. New York, Oxford University Press, 1951.

18. Laplace, L. B., Observations on the effect of an arteriovenous fistula on the human circulation. Am. J. M. Sc., 1935, 189, 497.

19. Epstein, F. H., Shadle, O., Ferguson, T., and McDowell, M., Cardiac output and intracardiac pressures in patients with arteriovenous fistulas. In preparation.

20. Holman, E., Arteriovenous Aneurysm; Abnormal Communications Between the Arterial and Venous Circulation. New York, Macmillan, 1937.

21. Schreiner, G. E., Freinkel, N., Athens, J. W., and Stone, W. L., III., Dye injection curves in traumatic arterio-venous fistulae in man. Federation Proc., 1952, 11, 141.

22. Harrison, T. R., Dock, W., and Holman, E., Experimental studies in arteriovenous fistulae: cardiac output. Heart, 1924, 11, 337. 
23. Warren, J. V., Nickerson, J. L., and Elkin, D. C., The cardiac output in patients with arteriovenous fistulas. J. Clin. Invest., 1951, 30, 210.

24. Gibbon, J. H., Jr., and Churchill, E. D., Changes in the pulmonary circulation induced by experimentally produced arteriovenous fistula. Arch. Surg., 1930, 21, 1188.

25. Transactions of the third conference on renal function, October 18-19, 1951. Josiah Macy Jr. Foundation, 1952, New York.

26. Selkurt, E. E., Hall, P. W., and Spencer, M. P., Influence of graded arterial pressure decrement on renal clearance of creatinine, $p$-aminohippurate and sodium. Am. J. Physiol., 1949, 159, 369.

27. Shipley, R. E., and Study, R. S., Changes in renal blood flow, extraction of inulin, glomerular filtration rate, tissue pressure and urine flow with acute alterations of renal artery blood pressure. Am. J. Physiol., 1951, 167, 676.

28. Smith, F. M., Miller, G. H., and Graber, V. C., The relative importance of the systolic and the diastolic blood pressure in maintaining the coronary circulation. Arch. Int. Med., 1926, 38, 109.

29. Green, H. D., The coronary blood flow in aortic stenosis, in aortic insufficiency and in arteriovenous fistula. Am. J. Physiol., 1936, 115, 94.

30. Smith, H. W., Rovenstine, E. A., Goldring, W., Chasis, H., and Ranges, H. A., The effects of spinal anesthesia on the circulation in normal, unoperated man with reference to the autonomy of the arterioles and especially those of the renal circulation. J. Clin. Invest., 1939, 18, 319.

31. Corcoran, A. C., Taylor, R. D., and Page, I. H., Circulatory responses to spinal and caudal anesthesia in hypertension: relation to the effect of sympathectomy. II. Effect on renal function. Am. Heart J., 1948, 36, 226.

32. Miles, B. E., deWardener, H. E., Churchill-Davidson, H. C., and Wylie, W. D., The effect on the renal circulation of pentamethonium bromide during anaesthesia. Clin. Sc., 1952, 11, 73.

33. Hooker, D. R., A study of the isolated kidney. The influence of pulse pressure on renal function. Am. J. Physiol., 1910, 27, 24.

34. Gesell, R. A., On the relation of pulse pressure to renal secretion. Am. J. Physiol., 1913, 32, 70.

35. Selkurt, E. E., Effect of pulse pressure and mean arterial pressure modification on renal hemodynamics and electrolyte and water excretion. Circulation, 1951, 4, 541.

36. Goodyer, A. V. N., and Glenn, W. W. L., Relation of arterial pulse pressure to renal function. Am. J. Physiol., 1951, 167, 689.

37. Starling, E. H., The fluids of the body. The Herter Lectures. Chicago, W. T. Keener and Co., 1909.

38. Peters, J. P., Body Water: The Exchange of Fluids in Man. Springfield, Ill., Charles C. Thomas, 1935.

39. Borst, J. G. G., and DeVries, L. A., The three types of "natural" diuresis. Lancet, 1950, 2, 1.
40. Asmussen, E., Christensen, E. H., and Nielsen, M., Uber die Kreislaufinsuffizienz in stehender Stellung bei normalem arteriellen Druck und herabgesetztem Minutenvolumen. Skandinav. Arch. f. Physiol., 1939, 81, 214.

41. Cargill, W. H., Sellers, S., and Shure, M., Induced variations in glomerular filtration rate and the urinary excretion of water and chloride. Proceedings of the Southern Society for Clinical Research, January 27, 1951. Am. J. Med., 1951, 11, 239.

42. Bazett, H. C., Thurlow, S., Crowell, C., and Stewart, W., Studies on effects of baths on man. II. The diuresis caused by warm baths, together with some observations on urinary tides. Am. J. Physiol., 1924, 70, 430.

43. Gauer, O. H., Henry, J. P., Sieker, H. O., and Wendt, W. E., Heart and lungs as a receptor region controlling blood volume. Am. J. Physiol., 1951, 167, 786.

44. Viar, W. N., Oliver, B. B., Eisenberg, S., Lombardo, T. A., Willis, K., and Harrison, T. R., The effect of posture and of compression of the neck on excretion of electrolytes and glomerular filtration: Further studies. Circulation, 1951, 3, 105.

45. Strauss, M. B., Davis, R. K., Rosenbaum, J. D., and Rossmeisl, E. C., Production of increased renal sodium excretion by the hypotonic expansion of extracellular fluid volume in recumbent subjects. J. Clin. Invest., 1952, 31, 80.

46. Brun, C., Knudsen, E. O. E., and Raaschou, F., The influence of posture on the kidney function. I. The fall of the diuresis in the erect posture. Acta med. Scandinav., 1945, 122, 315.

47. Bobb, J. R. R., Lillehei, C. W., and Visscher, M. B., Induction of experimental heart failure with arteriovenous fistulae. Federation Proc., 1952, 11, 15.

48. Epstein, F. H., and Ferguson, T. B., Unpublished observations.

49. Elkinton, J. R., and Taffel, M., Prolonged water deprivation in the dog. J. Clin. Invest., 1942, 21, 787.

50. Weech, A. A., Snelling, C. E., and Goettsch, E., The relation between plasma protein content, plasma specific gravity and edema in dogs maintained on a protein inadequate diet and in dogs rendered edematous by plasmapheresis. J. Clin. Invest., 1933, 12, 193.

51. Weech, A. A., Wollstein, M., and Goettsch, E., Nutritional edema in the dog. V. Development of deficits in erythrocytes and hemoglobin on a diet deficient in protein. J. Clin. Invest., 1937, 16, 719.

52. Netravisesh, V., and White, H. L., Effects of hemorrhage and transfusion on renal circulation and sodium excretion in dogs. Am. J. Physiol., 1950, $161,442$.

53. Lombardo, T. A., Eisenberg, S., Oliver, B. B., Viar, W. N., Eddleman, E. E., Jr., and Harrison, T. R., Effects of bleeding on electrolyte excretion and on glomerular filtration. Circulation, 1951, 3, 260. 
54. Wilkins, R. W., Culbertson, J. W., Burrows, B. A., Tinsley, C. M., Judson, W. E., and Burnett, C. H., Antidiuresis and renal vasoconstriction following venous congestion of the limbs in normal, hypertensive and splanchnicectomized subjects. J. Clin. Invest., 1949, 28, 819.

55. Judson, W. E., Epstein, F. H., Tinsley, C .M., Burrows, B. A., and Wilkins, $R$. W., The hemodynamic and renal functional effects of venous congestion of the limbs in patients with diabetes insipidus. J. Clin. Invest., 1950, 29, 826.

56. Farber, S. J., Alexander, J. D., and Eichna, L. W., Renal hemodynamics and salt and water excretion during induced congestion of the inferior vena cava of man. J. Clin. Invest., 1951, 30, 638.

57. Goodyer, A. V. N., Relman, A. S., Lawrason, F. D., and Epstein, F. H., Salt retention in cirrhosis of the liver. J. Clin. Invest., 1950, 29, 973.

58. Post, R. S., Decrease of cardiac output by acute pericardial effusion and its effect on renal hemo- dynamics and electrolyte excretion. Am. J. Physiol., 1951, 165, 278.

59. Davis, J. O., Lindsay, A. E., and Southworth, J. L., Mechanisms of fluid and electrolyte retention in experimental preparations in dogs. I. Acute and chronic pericarditis. Bull. Johns Hopkins Hosp., 1952, 90, 64.

60. Fishman, A. P., Stamler, J., Katz, L. N., Miller, A. J., Silber, E. N., and Rubenstein, L., Mechanisms of edema formation in chronic experimental pericarditis with effusion. J. Clin. Invest., 1950, 29, 521.

61. Levy, M. H., and Berne, R. M., Effects of acute reduction of cardiac output upon the mechanisms of sodium excretion in the dog. Am. J. Physiol., 1951, 166, 262.

62. Barger, A. C., Richardson, G. S., and Roe, B. B., A method for producing chronic cardiac failure in dogs. Proc. Soc. Exper. Biol. \& Med., 1950, 73, 113.

\section{SPECIAL NOTICE TO SUBSCRIBERS}

Post Offices will no longer forward the Journal when you move.

Please notify The Journal of Clinical Investigation, Business Office, 622 West 168th Street, New York 32, N. Y. at once when you have a change of address, and do not omit the zone number if there is one. 